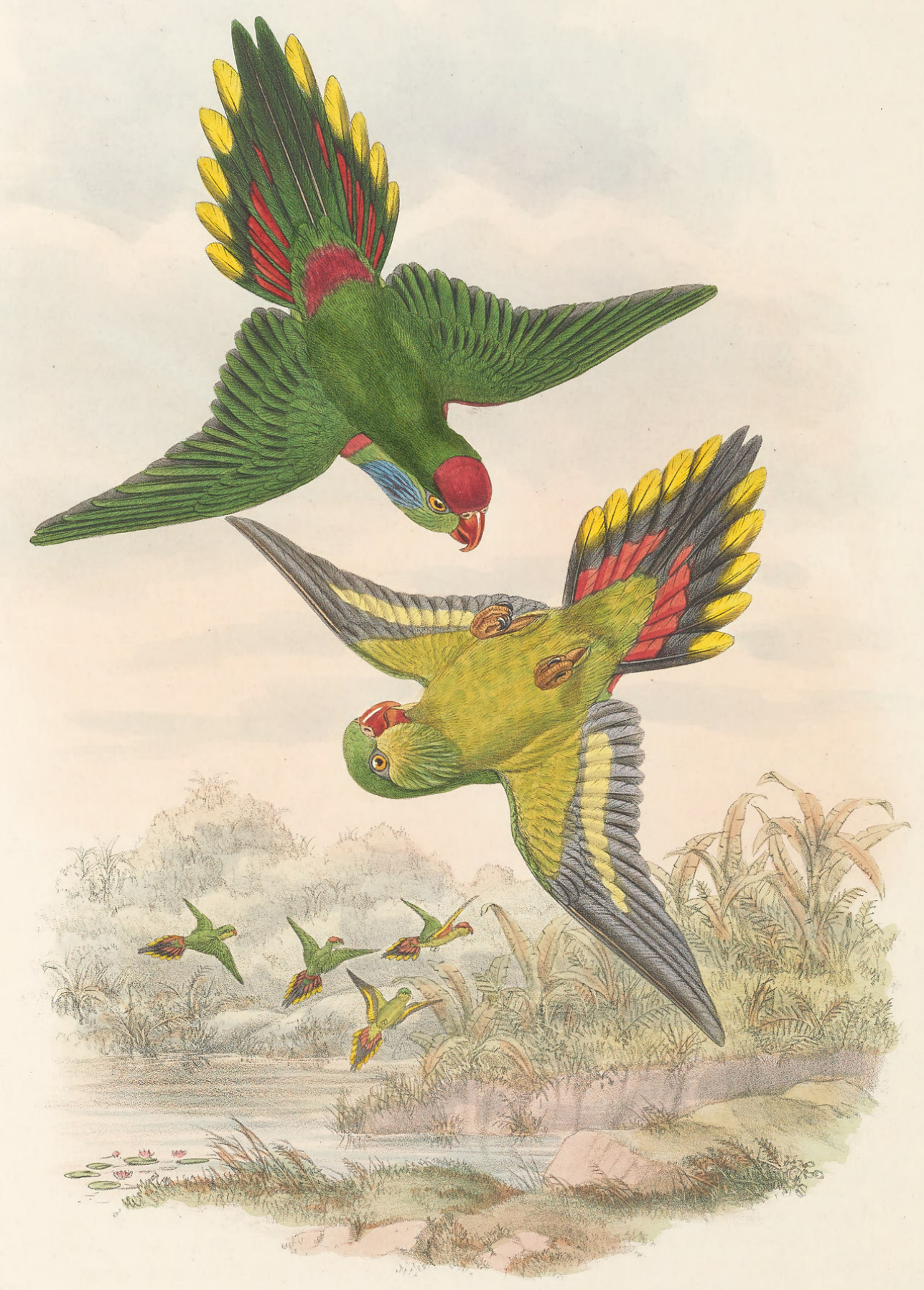




\title{
PSITTEUTELES RUBRONOTA'TUS.
}

\author{
Red-backed Lorikeet.
}

Coriphilus rubronotatus, Wallace, P. Z. S. 1862, p. 165

Charmosyna rubronotata, Wallace, P. Z. S. 1864, p. 293.

Trichoglossus rubronotatus, Finsch, Pap. ii. p. 876 (1868).

Nanodes rubronotatus, Schlegel, Mus. P.-B. Revue Psitt. p. 51 (1874).

Trichoglossus rubronotatus, Meyer, Sitzb. d. k.-k. Akad. d. W. zu Wien, lxix. p. 400 (1874)

Trichoglossus kordoanus, Meyer, Verh. d. k.-k. zool.-bot. Ges. zu Wien, 1874.

Charmosyna kordoana, Salvadori, Ann. Mus. Civ. di Genova, vii. 1875, p. 212.

DR. Meyer, ever anxious to advance Papuan ornithology, has obligingly forwarded to me seven specimens of a little Lorikeet, which he considers to be two different birds; and he believes that his Trichoglossus kordoanus should stand as a species, and not as a synonym to Mr. Wallace's Coriphilus rubronotatus. But, after having given the subject my closest attention and, moreover, after consulting the opinions of others, I can come to no other conclusion than that the specimens sent to me are identical or have insufficient characters to separate them. Trifling differences, it is true, occur among the seven specimens; but they are not more, nay, not even so much as those that have occurred to me many times before-differences attributable, perhaps, to locality or to some cause equally unimportant. As Dr. Meyer, however, still clings to his opinion and has, moreover, taken the trouble to forward me a translation of his paper on the subject with additional remarks, it is right that I should give his views on the subject.

He remarks :- "Trichoglossus rubronotatus was discovered by Mr. Wallace on the island of Salwati at the north-west extremity of New Guinea, and has since been procured by Dr. Bernstein in the same district, but was never figured before, specimens even now being very rare. It was only in one place in New Guinea, in May 1873, that I obtained this lovely bird, viz. near Rubi, the southern point of the great Geelvinks Bay; and in $1874 \mathrm{I}$ published some notes respecting it, which I beg to be allowed to reproduce here.

"Dr. Finsch says of rubronotatus:- 'A beautiful bird, representing the Trichoglossus placens on Salwati and the north-west coast of New Guinea;' but, inasmuch as the two species occur together (mine were both obtained near Rubi), they must rather be considered parallel forms and not representations of each other, the adult male only being known till lately, and described by Dr. Finsch in detail, although he does not mention the sex of the bird.

"A short time before I published these notes I had described a similar form from the island of Mysore, in the north of the Geelvinks Bay, under the name of Trichoglossus kordoanus, a female, and the only one that had come under my notice. I then stated the differences between the females of the two forms to be as follows :- $T$. knrdoanus. Cheeks and sides of the neck bright bluish green, whereas in T. mbronotatus the cheeks are of a darker tint, with yellow stripes, and the sides of the neck light grass-green, like the under surface of the whole body; besides which the red of the uropygium in $T$. kordoanus is much more vivid than the same colour in the males of $T$. rubronotatus. The irides are bright yellow; bill and cere bright red; feet of a somewhat lighter tint; claws grey. The tongue is a regular brush; the stomach contained only flower-sap.

"I imagined that the males would prove to be still more distinct, as the difference between the females was so marked; this, however, did not prove to be the case. The Dresden Museum possesses a male specimen of the Mysore bird; the chief points of difference between this and $T$. rubronotatus are as follows :Under surface, especially on throat, bluish green instead of the yellowish tint in T. rubronotatus ; the red of the uropygium brighter and more extensive than in the New-Guinea bird, where it only consists of a few feathers even in the male when in full plumage; besides which the red on the sides of the breast appears to extend more to the centre in $T$. kordoanus than in $T$. rubronotatus; and, finally, the green of the upper surface of the former is of a more brilliant hue than in the latter.

"These differences are not great, yet they are conspicuous and cannot be overlooked or underrated ; their real significance, however, lies in the fact that they coincide with the geographical separation, and in their constancy. In our Darwinian days but few naturalists will dispute that insular forms are to be regarded as directly derived from continent ones, nor will the value of the small differences be disputed. When sufficient materials of similar deviations from a parent stock are collected, the reasons of these variations may, perhaps, be rendered more clear, and the laws by which they sometimes take place be more fully recognized."

The principal figures are of the size of life. 


\section{$2 \mathrm{BHL}$ Biodiversity Heritage Library}

Gould, John and Sharpe, Richard Bowdler. 1877. "Psitteuteles rubronotatus, Red-backed Lorikeet [PI. 16]." The birds of New Guinea and the adjacent Papuan islands : including many new species recently discovered in Australia 5(V), -. https://doi.org/10.5962/p.322860.

View This Item Online: https://www.biodiversitylibrary.org/item/230441

DOI: https://doi.org/10.5962/p.322860

Permalink: https://www.biodiversitylibrary.org/partpdf/322860

\section{Holding Institution}

Smithsonian Libraries

\section{Sponsored by}

Biodiversity Heritage Library

\section{Copyright \& Reuse}

Copyright Status: Public domain. The BHL considers that this work is no longer under copyright protection.

This document was created from content at the Biodiversity Heritage Library, the world's largest open access digital library for biodiversity literature and archives. Visit BHL at https://www.biodiversitylibrary.org. 